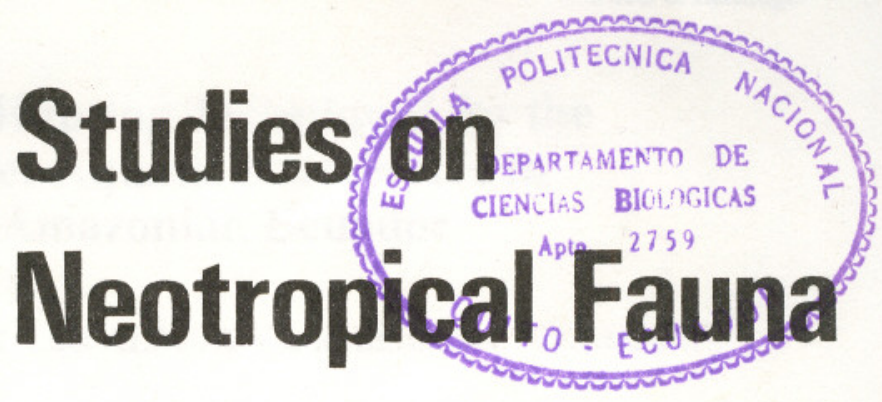 and Environment
}

Editorial Board:

\author{
L. Brundin \\ E. Du Bois \\ Reymond Marcus \\ J. Gery \\ E.F. Kilian \\ H.W. Koepcke \\ J. Reichholf
}

Editor-in-chief:

E.J. Fittkau

\section{Stockholm}

Sao Paulo

Saint-Cyprien

Giessen and Valdivia

Hamburg

München

München 


\title{
Siona Hunting Techniques for the Larger Aquatic Vertebrates in Amazonian Ecuador
}

\author{
Robert M. TIMM, Luis ALBUJA V. and Barbara L. CLAUSON
}

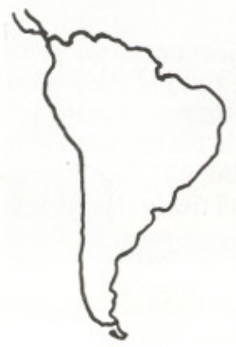

TIMM, R.M., L. ALBUJA V. \& B.L. CLAUSON (1989): Siona Hunting Techniques for the Larger Aquatic Vertebrates in Amazonian Ecuador. Studies on Neotropical Fauna and Environment 24 (1989), pp. 1-7.

Robert M. Timm, Museum of Natural History, The University of Kansas, Lawrence, Kansas 66045, USA.

Luis Albuja V., Departamento de Ciencias Biológicas, Escuela Politécnica Nacional, Apartado 2759, Quito, Ecuador.

Barbara L. Clauson, Museum of Natural History, The University of Kansas, Lawrence, Kansas 66045, USA.

\section{Introduction}

The Siona Indians along the Río Cuyabeno of Amazonian Ecuador rely heavily upon aquatic vertebrates as a major source of animal protein (Vickers, 1983). Although most of the protein consumed comes from small to medium-sized fish, which are either speared or captured with hook and line, the larger aquatic vertebrates were historically important components of the diet and continue to play a role today. Along deeper, faster flowing rivers such as the Aguarico and Eno, terrestrial and arboreal vertebrates are much more important in the diet of the Siona. There the prime fishing period is during the dry season when water levels are low and large migratory catfish can be hooked in the deeper pools of the river beds (W. Vickers, Florida International Univ., Miami, pers. comm.).

The Cuyabeno region is a unique habitat because of the large, numerous lagoons. Small to medium sized fish are reliable year round, paiche can be taken, especially in the dry season when they are stranded in oxbow lakes "cut off from the main river, and manatees are present. Terrestrial hunting is difficult due to the swampy nature of the river basin.

The larger aquatic vertebrates hunted by the Siona include Amazonian manatees, Trichechus inunguis (Mammalia: Trichechidae); paiche, Arapaima gigas (Pisces: Osteoglossidae); giant sideneck river turtles, Podocnemis expansa and Podocnemis unifilis (Reptilia: Pelomedusidae); and spectacled caiman, Caiman crocodylus $[=C$. sclerops] (Reptilia: Alligatoridae). Manatees or "vaca marina" are the largest mammals on the South American continent, weighing up to $450 \mathrm{~kg}$. Paiche or "pirarucú" are the largest freshwater fish in South America, reaching a length of over $3 \mathrm{~m}$ and a weight of $150 \mathrm{~kg}$ (Goulding, 1981). The giant sideneck river turtle or "charapa", P. expansa, is the most common turtle the Siona 
hunt and is one of the largest of the freshwater turtles, weighing from 30 to $90 \mathrm{~kg}$ (Smith, 1979; Pritchard and Trebbau, 1984). Spectacled caimans or "caimán de anteojos" are abundant in oxbows and lagoons reaching a length of $2.4 \mathrm{~m}$ and may weigh up to $50 \mathrm{~kg}$ (Medem, 1981).

The objectives of this report are to document hunting techniques used by the Siona of Amazonian Ecuador for manatees, paiche, giant sideneck river turtles, and spectacled caiman. Harpoons and methods used for harvesting these animals are described and compared.

\section{Methods}

From late September through early November of 1983 we searched for Amazonian manatees in the Río Aguarico and Río Napo systems of Amazonian Ecuador as part of a faunal survey of the region. One of the objectives of the study was to document the distribution, ecology, and harvest of manatees (Timm et al., 1986). From 27 September to 2 October we searched for manatees in the lagoon region of the upper Río Cuyabeno within Reserva de Producción Faunística Cuyabeno $\left[00^{\circ} 00^{\prime}, 76^{\circ} 11^{\prime} \mathrm{W}\right.$, el. $210 \mathrm{~m}$ ]. A Siona family from the village of Puerto Bolivar served as our guides and freely shared with us their knowledge of the local wildlife and Siona hunting techniques.

\section{Hunting Techniques of the Siona}

The harpoons used by the Siona to kill manatees, paiche, and caiman are of similar design and consist of four parts - a steel tip, shaft, pulling line, and float. The steel manatee harpoon tip we examined (Fig. 1) is $130 \mathrm{~mm}$ in length and has two prominent backward projecting barbs. The tip, barbs, and shank are flattened. Posteriorly, it has a hollowed, conical receptacle to receive the long wooden shaft. The tip itself was hammered out of a steel rod some $110 \mathrm{~mm}$ in length and $9 \mathrm{~mm}$ in diameter. The rods are purchased locally and are used in building construction. The conical receptacle was pounded from a single 16 gauge lead slug. At the base of the steel tip, a lip of steel must protrude laterally from the shank, as the lead receptacle is firmly attached to the shank. There is no external sign of attachment.

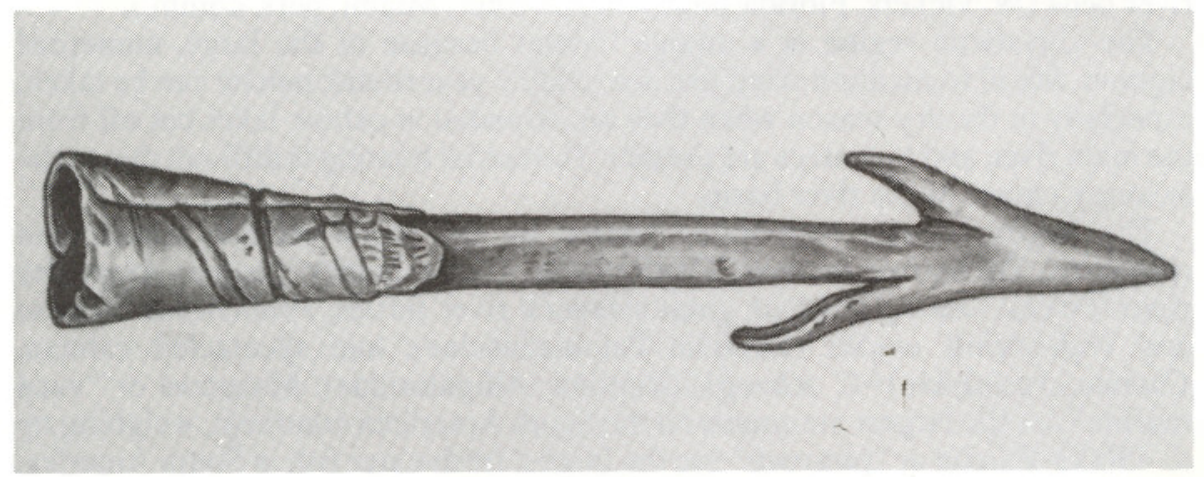

Fig. 1 Siona steel manatee harpoon with lead base, made by the Siona and typical of harpoons they use for manatees. Illustration by Rosanne Miezio. 


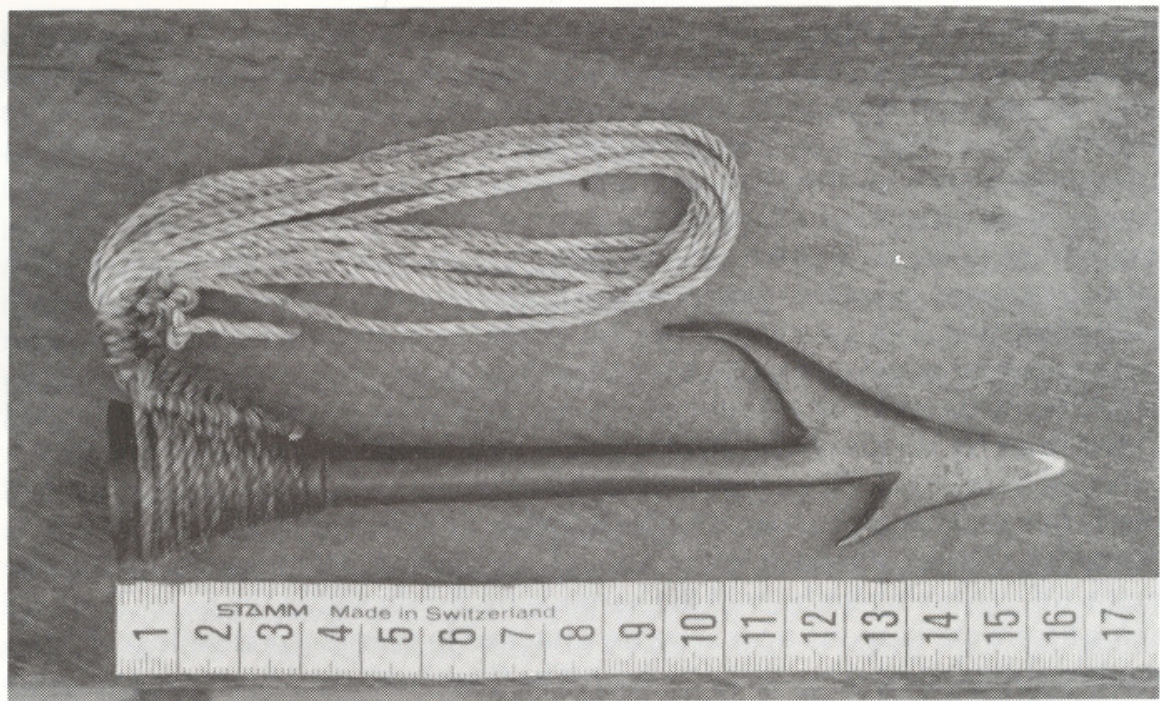

Fig. 2a. Commercially produced steel harpoon currently used by the Siona for paiche. Note the pambil cord knotted at base with eight posteriorly projecting loops for the attachment of tip to pulling line.

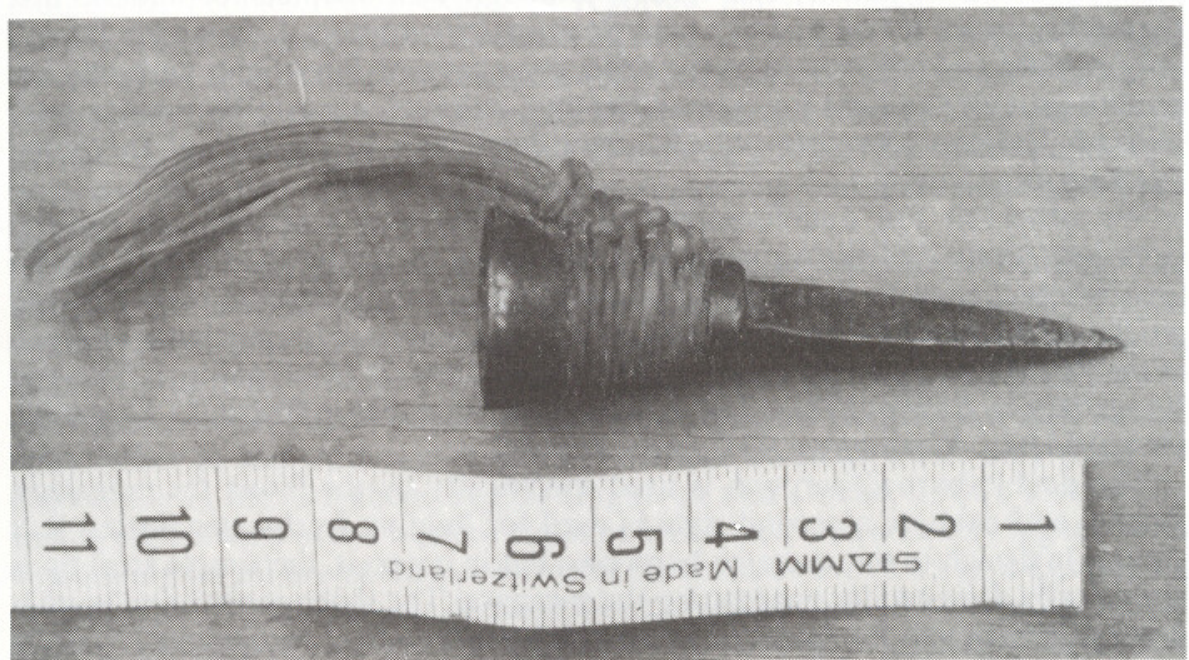

Fig. 2b. Siona turtle harpoon tip. Photographs by Barbara L. Clauson.

The cord used to affix the harpoon tip to the pulling line and shaft (Fig. 2a) is known as "pambil", and is made from the fibers of palm leaflets. The newly developing embryonic leaflets of Astrocaryum sp. (Palmae) are picked and the fibers stripped from the interconnecting tissue. Several fibers are then rolled together to produce a single strand, and two strands are rolled together to produce 
the cord. Pambil is perhaps the strongest local fiber available to the Siona. It is thin, light, flexible, and yet extremely durable. Pambil serves the Siona for a wide array of uses. Because of its lightness, strength, and resistance to rot, it is the preferred plant fiber for making cord for hunting and fishing gear. Other palms utilized as a source of fibers for cord include Catostigma sp., Geonoma sp., Iriartea cornuta, and Socratea sp. (Lcdo. Jaime Jaramillo, Universidad Católica, Quito, pers. comm.). The cord is knotted around the conical base of the harpoon with eight short loops extending posterior from the base. These loops are tied to the pulling line, which is also made of pambil. Eight loops provide more strength than a single loop of equal diameter. A wooden float is attached to the pulling line to mark the location of the harpooned animal. The shaft is three meters long and carved from fig shoots (Ficus, Moraceae) or chonta (Bactris casiopaes, Palmae).

As told to us by our Siona guide, manatees, paiche, and caiman are approached quietly in open dugout canoes, and the harpoon thrown from a distance of only a few meters. Once imbedded in the animal, the tip detaches from the shaft. The backward-projecting barbs hold the harpoon tip firmly within the flesh. The cord running from the harpoon tip is securely attached to a large wooden float of balsa and then to a cord held by the harpooner. The float has a dual function, to tire the wounded animal as it pulls the float, and to mark the location of the animal. Once exhausted, the harpooned animal is hauled to the surface and quickly dispatched with a machete. Hunting is best in the early morning or at dusk, especially if it is cloudy. Manatees, paiche, and turtles, although well-adapted for aquatic life, regularly surface for air and can then be spotted by hunters. Caiman are hunted only at night and are located by the reflective eyeshine. Flashlights currently are used to provide the light for caiman hunting, although historically torches were utilized. Caiman represent only a minor food item in the diet of the Siona (Vickers, pers. comm.).

We observed the double-barbed style of harpoon elsewhere on several occasions along the Río Aguarico and Río Napo, including the Lagarto Cocha area where a commercial meat hunter used this tip style for both manatees and paiche. The entire harpoon is of similar design to that used for paiche or pirarucú in the Rio Madeira area of Brazil as reported by Goulding (1981: Fig. 3.20), near Itacoatiara by Smith (1981a: Fig. 4.7), and for manatees in Brazil (D. Domning, Howard Univ., Washington, D.C., pers. comm.).

The double-barbed harpoon is used specifically by the Siona for manatees, paiche, and caiman; a second style is used for hunting freshwater turtles. It is similar in design to the manatee harpoons; but in contrast, the simple steel tip is specifically designed for penetrating the carapace. The sharp penetrating point is $4 \mathrm{~cm}$ in length and four-sided (Fig. 2b). A hollow conical receptacle $2.5 \mathrm{~cm}$ in length is used to affix the tip to the shaft. This is the only other type of harpoon used by the Siona for aquatic vertebrates. The metal harpoon tip itself is similar to that described by Smith (1979: Fig. 3) for hunting turtles in Brazil, although the Siona's is $25 \%$ larger. The method of attachment of the tip to the shaft does differ from that used in Brazil. As with the double-barbed harpoons, the Siona employ a complex knot with several backward-projecting loops for attachment, thereby creating a strong, reinforced system to haul in the harpooned turtle (Fig. 2b). The attachment rope described by Smith (1979) includes only a single backwardprojecting line. 
The Siona locate turtles by following the trails of rising air bubbles from swimming turtles. They then thrust their harpoon, attempting to penetrate the carapace. If they are successful, a small hole is punched through the bony carapace with the harpoon tip penetrating beneath the bone. Once the tip is imbedded, it detaches from the shaft. The attachment cord for the harpoon is located offcenter, some $80 \%$ of the distance from the tip. Thus, as the cord is jerked and pulled taut, the harpoon tip shifts to lie perpendicular to the entrance hole, insuring that the prey is firmly secured. Aquatic turtles currently are taken infrequently and those being primarily from the middle and lower Río Aguarico proper during the nesting season of November and December (Vickers, pers. comm.).

\section{Discussion}

Early explorers found manatee meat routinely available in local villages throughout the Amazon basin. Prior to contact with western man, indigenous tribes utilized "harpoons fitted with shell points" to hunt manatees (Smith, 1981b: p. 185). In addition to providing a source of meat and oil, the manatee furnished dense bones for utensils and thick hides which were used for war shields (Nimuendajú, 1952; Smith, 1981b). Yet even though heavily exploited by the indigenous peoples, early explorers reported that manatees were abundant (Acuña, 1891; Medina, 1934). Smith (1981b: p. 185) stated "T. inunguis has long served as an important food resource for inhabitants of the Amazon basin. In pre-contact times, they were hunted by aborigines, as evidenced by bones found in shell mounds ... In spite of millennia of hunting pressure by natives, manatees were still abundant in early colonial time, suggesting that there must have been cultural checks to over-exploitation."

Siona game harvesting would best be described as subsistence hunting. The Siona obtain a wide array of animals for food, however, the majority of their animal protein is obtained from fish, which are either speared or caught with hook and line. Due to the nature of their hunting techniques there appears to be little to no negative impact upon populations of game species. Hunting is a skill passed from father to son. Although today the number of Siona totals only some 50 individuals in the Cuyabeno region (Figueroa and Coello, 1980), historically Indian populations in the western Amazon basin were considerably higher. With exploration for oil in eastern Ecuador and the construction of new roads bringing in settlers and the military, the demand for animal protein has increased. Increased hunting pressure apparently has caused the population of manatees to decline severely. The Siona now seldom hunt manatees, informing us that there are too few; at Puerto Bolivar they have not hunted manatees for the past seven years. William Vickers informs us that three manatees were killed in the Cuyabeno region during June-August 1980. The impetus for their ban on hunting is conservation of the remaining animals. During the rainy season, manatees are present in the lagoons which the Siona regularly hunt and fish; they remain an easily obtainable source of animal protein. The lagoon region of the upper Cuyabeno is now a reserve, Reserva de Producción Faunística Cuyabeno. Only the indigenous people, the Siona, are allowed to hunt and fish there, although 
poaching does occur. The Siona, as with most indigenous tribes in the Amazon basin, have a complete taboo on the killing and eating of the freshwater dolphin or "fanja", Inia geoffrensis, which are common in the Cuyabeno lagoons.

The Siona along the Cuyabeno actively manage the waterways that they rely upon for transportation. Fallen trees across streams are cut if the passage of their canoes is blocked. The courses of streams are altered by cutting through banks of meanders and channeling flood waters to create more efficient canoe routes. Several years may pass before the new channel is passable for canoes. Water hyacinths, Eichhornia crassipes, Eichhornia diversifolia, and Eichhornia heterosperma (Pontederiaceae) are abundant in the lagoon regions of Amazonian Ecuador. Water hyacinths are one of the primary foods of manatees in Ecuador (Timm et al., 1986). Manatees may help to control these emergent plants and keep stream channels open. In other areas where manatees have been decimated by man, water hyacinths have choked out channels to the point where they are totally impassable (Bertram and Bertram, 1973). Preservation of the Siona's waterways would be an added benefit of manatee conservation.

Although manatees were historically important protein sources for the Siona, they currently practice a self-imposed ban on manatee hunting because of low manatee populations. The Siona, however, do continue to harvest both paiche and giant sideneck river turtles even though their populations are currently threatened.

\section{Acknowledgements}

We are grateful to the people of Puerto Bolivar for freely sharing with us their hunting lore and homes. Ramiro Barriga, Myriam Ibarra, Gustavo Orcés, and Donald J. Stewart provided logistic assistance in Ecuador. Daryl P. Domning, Alfred L. Gardner, Myriam Ibarra, Donald J. Stewart, and William T. Vickers critically read earlier drafts of this manuscript and provided valuable suggestions. We thank the Comandancia General del Ejército Ecuatoriano, the Ministerio de Agricultura y Ganadería for assistance and logistic support. Timothy Plowman of the Field Museum identified the voucher specimens of aquatic plants for us. This project was funded in part by a grant from the National Science Foundation, INT-8303194, with supplemental support from the Escuela Politécnica Nacional, Field Museum of Natural History, and the Chicago Zoological Society.

\section{Literature}

ACUÑA, P.C. 1891. Nuevo descubrimiento del Gran Río de las Amazonas. Madrid. 235 pp.

BERTRAM, G.C.L. and C.K.R. BERTRAM. 1973. The modern Sirenia: their distribution and status. Biol. J. Linnean Soc. 5(4): 297-338.

FIGUEROA S., S. and F. COELLO H. 1980. Proyecto de limitación de territorios nativos Siona Secoya - Cofán y Huaorani parametro biológico. Ministerio de Agricultura y Ganadería, Dirección General de Desarrollo Forestal, Departamento de Administración de Areas Naturales y Vida Silvestre. Guayaquil. No. 17-40, Quito, Ecuador. 35 pp. + appendix and maps.

GOULDING, M. 1981. Man and fisheries on an Amazon frontier. Developments in Hydrobiology 4. Dr. W. Junk Publishers, London. 137 pp.

MEDEM, F. 1981. Los Crocodylia de Sur América. Volumen 1. Los Crocodylia de Colombia. Colciencias, Bogotá, Colombia. 354. pp.

MEDINA, J. 1934. The discovery of the Amazon according to the account of Friar Caspar de Carvajal. American Geographical Society, New York. 
NIMUENDAJÚ, C. 1952. The Tukuna. Univ. California Publ., American Árẹhateology and Êthnolloggy 45: $x+1-210$.

PRITCHARD, P.C.H. and P. TREBBAU. 1984. The turtles of Venezuela. Contributions to Herpetology, Society for the Study of Amphibians and Repriles 20 viii $P 11-414$.

SMITH, N.J.H. 1979. Aquatic turtles of Amazonia: an endangered resource. Biol. Consenv. 16(3): $165-176$.

SMITH, N.J.H. 1981a. Man, fishes, and the Amazon. Columbia University Pres $\hat{s}$, New York.

SMITH, N.J.H. 1981b. Caimans, capybaras, otters, manatees and man in Amazonia. Biol. Conserv? 19(3): 177-187.

TIMM, R.M., L. ALBUJA V. and B.L. CLAUSON. (1986). Ecology-distribution, harvesr, and conservation of the Amazonian manatee Trichechus inunguis in Ecưdor.-Biotropica 18(2): 150-156.

VICKERS, W.T. 1983. The territorial dimensions of Siona-Secoya and Encabellado adaptation. Pp. 451-478, in Adaptive responses of native Amazonians (Hames, R.B. and W.T. Vickers, Eds.). Academic Press, New York. 516 pp. 
00
00
00
00
00
00 


\section{STUDIES ON NEOTROPICAL FAUNA AND ENVIRONMENT Ecology and Systematics}

This international journal is issued in volumes of 4 numbes (of about 64 pages each), not more than one volume being published annually. It deals with the ecology, systematics and distribution of the neotropical fauna. It was originally published with the title Beiträge zur neotropischen Fauna (Vols. 1-6) and Studies on the Neotropical Fauna (Vols. 7-10).

Alle correspondence regarding subscriptions should be sent to the publishers.

SWETS \& ZEITLINGER B.V.

Publishing Department

P.O. Box 825

2160 SZ Lisse, The Netherlands.

Manuscripts, illustrations and all communications relative to them should be addressed to the Editor-in-Chief, Prof. Dr. E.J. Fittkau, Zoologische Staatssammlung, Münchhausenstrasse 21, D 8000 München 60 , Western Germany. For instructions to authors with regard to the manuscript see below and inside of back cover.

Printed in The Netherlands by Offsetdrukkerij Kanters B.V., Alblasserdam

(c) Copyright 1988 by Swets \& Zeitlinger B.V., Lisse

Published quarterly

Permission to photocopy for internal or personal use or the internal or personal use of specific clients is granted by Swets \& Zeitlinger for libraries and other users registered with the Copyright Clearance Center (CCC) provided that the stated fee per copy is paid directly to the CCC, 21 Congress Street, Salem, MA 01970. Special requests should be addressed to Swets Publishing Service, Box $825,2160 \mathrm{SZ}$ Lisse, The Netherlands. 